\title{
\$sciendo
}

Ethics \& Bioethics (in Central Europe), 2018, 8 (1-2), 63-79

DOI:10.2478/ebce-2018-0006

\section{Ethico-political engagement and the self-constituting subject in Foucault}

\section{Lenka Ucnik ${ }^{1}$}

\begin{abstract}
Foucault is critical of the tendency to reduce all social and political problems according to predetermined ends and verifiable procedures. For Foucault, philosophical activity is a condition of possibility for the articulation of the question of the self. Inspired by his work on the desiring subject, Foucault begins to explore the ethical and political implications of self-care for modern day concerns. He presents an account of self-care that centres on developing an attitude that questions the personal relationship to truth, and puts to test those ideas and truths held most dearly. Processes of self-care evaluate the consistency between those truths a person regards as necessary and a person's actions in the world. Interested in the ways in which people see themselves as subjects, Foucault directs his attention to the connection between systems of knowledge, power, and practices of the self. Crucial to Foucault's process is the recognition that the self-subject is not given and does not have ontological precedence, and that subjectivity is transformable. By finding the lines and fractures in external and internal modes of objectification Foucault hopes to open up the space of freedom to bring about transformative events. The care of the self serves as a form of critique and resistance where it is both a way of living and acting in the world, and a critical response to a particular time and place.
\end{abstract}

Keywords: Foucault, ethics, politics, aesthetics, care of the self, subjectivity, freedom, transformation

Foucault's account of the subject is often criticised on three main fronts: (1) that his notion of subjectivity is defined entirely by external knowledge and power relations, lacks autonomy and precludes the possibility for resistance. According to this criticism, in the Foucauldian schema the possibility for personal resistance seems impossible because the subject is understood to be constituted solely by a complex amalgam of external forces; (2) Foucault's attempt to develop an account of self-constitution in his later work on the care of the self goes against his earlier claims on subjectivity referred to in point 1 , and amounts to nothing more than an overemphasis on selfishness and self-obsession. Regarding this second argument, some critics consider it contradictory to have an understanding of subjectivity that is both externally and internally constituted. Furthermore, others, predominantly from the AngloAmerican tradition, consider Foucault's description of self-care to be, at best, a modern form of dandyism and, at worst, a frightening obsession with an aesthetics of self-creation that could have potentially dangerous results. The underlying fear with this line of attack is that without recourse to a prevailing moral structure the idea of the self to be worked upon like an artwork could easily transform into a politics that treats the masses as raw material to be moulded for diabolical ends; (3) finally, Foucault's interpretation of subjectivity fails to adequately engage with the role of the other (or others). This third point, considers Foucault's care of the self to be inadequate because of its failure to provide a satisfactory account of the important relationship between the self and others.

In this paper, I will contest the first and second line of criticism and claim that the idea of resistance has always been key feature throughout Foucault's work, and that there is no contradiction in his early and late account of subjectivity. I will not directly discuss the third criticism concerning Foucault's lack of engagement with the other however, in my discussion on the first two points I will minimally allude to the possibility that Foucault's account of the

\footnotetext{
${ }^{1}$ Monash University (Australia); email: lenka.ucnik@monashcollege.edu.au
} 
self does take into account the relationship between the self and others in some respect. Nonetheless, I do acknowledge that regardless of my claim that Foucault does include the role of the other in his conception of the self, it is not as easily countered as the first two points. Due to a lack of any detailed discussion on Foucault's part regarding the self and the other, to argue for or against his failure on this front comes down, in part, to interpretation rather than solid, irrefutable argument. Leaving the issue of the other to one side, my primary aim in this paper is to demonstrate that the possibility for resistance is a central theme throughout Foucault's career and that prior to the 1980s this was predominantly implicit. Only in his final work on the care of the self does Foucault directly discuss resistance and freedom framed in terms of processes of self constitution and its effects on ethical and political action.

To clarify the relationship between self-care, self constitution and ethico-political engagement (resistance), I first look at Foucault's interest in the question of self-constitution and ethico-political practice. I then outline the influence of Pierre Hadot's work on Foucault's care of the self and contrast Hadot's account of philosophy as a way of life with Foucault's aesthetics of existence. I then expand the idea of the relationship between an aesthetics of existence and the subject of ethics more broadly to demonstrate how ethics, in Foucault, becomes the mediator between the subject and knowledge-power, as well as being the site for personal resistance to external forces. Elaborating on Foucault's conception of freedom I demonstrate how, in his ethics of self-care, Foucault attempts to discover transgressive modes of thinking and living that are not simply products of normalizing forces (or "power" to use Foucault's term). Following this, I compare Foucault's notion of an aesthetics of existence with more "traditional" accounts of moral behaviour. As part of this comparison, I consider a common criticism of Foucault - that his account of ethics is merely an obsession with the self, amounting to no more than a modern form of dandyism. This line of attack, in its refusal to consider any significant relation between the ethical and aesthetic, is limited in its capacity to understand Foucault's project - and more significantly, ignores the insights that the aesthetic dimension of the ethical can disclose. Finally, I connect all of these elements to highlight how a care of the self not only offers a possibility for a dynamic ethical account, but also presents an alternative view of ethico-political engagement more generally.

\section{Ethico-political practice and the self-constituting subject}

Foucault develops his interest in ethico-political practices of self-constitution while writing The History of Sexuality. During this time, he comes to realise that his historical account of sexuality and the sexual subject includes three modes of objectification that affect the constitution of subjectivity, and can only be understood relationally: truth, power and ethics (or individual conduct). ${ }^{2}$ The first mode - truth - concerns the scientific formations that refer to sexuality. The second mode-power-deals with regulating systems of power and concerns practices of manipulation and examination. The third mode - ethics - concerns ways in which individuals establish a relationship to the self, to facilitate self-understanding and identify themselves as subjects of sexuality. Foucault recognises that he has explored the first two modes in detail in previous works, but the third mode on the self-constituting subject is noticeably lacking among the theoretical "tools" at Foucault's disposal. Acknowledging that any account of the experience of sexuality is incomplete without a critical and historical analysis of the desiring subject, Foucault turns his attention to this third mode of objectification-ethics.

Interested in the ways in which people see themselves as subjects, Foucault directs his attention to the connection between systems of knowledge, power, and practices of the self.

\footnotetext{
2 "I tried to mark out three types of problems: that of truth, that of power, and that of individual conduct. These three domains of experience can be understood only in relation to each other and only with each other" (Foucault, 1989c, p. 318).
} 
He aims to show that there is no single thing that is a "sexual subject" but that the experience of sexuality is an amalgam of external forces affecting the subjective experience, as well as internal forces leading people to recognise themselves as "this" or "that" kind of sexual subject. ${ }^{3}$ In examining the history of sexuality as a form of experience rather than a behaviour, Foucault disrupts commonly held conceptions of the sexual subject and the experience of sexuality. Foucault says in an interview: "Let it be clearly understood that I am not making a history of mores, of behaviour, a social history of sexual practice, but a history of the manner in which pleasures desires and sexual behaviors have been problematized, reflected upon and thought about in Antiquity in relation to a certain art of living" (Foucault, 1989b, p. 294).

Foucault clarifies his interest in different "problematizations" does not mean the representation of a pre-existing object or the creation of an object through discourse, but a multitude of discursive and non-discursive practices that, "make something come into the play of the true and false, and constitute an object of thought" (Foucault, 1989b, p. 296). These different practices can come in the form of moral reflection, scientific knowledge, political analysis or the care of the self (among many others).

The apparent redirection of his work from knowledge and power to self-constitution and lived practice required Foucault to defend his interest in the care of the self against criticism that it undermines this earlier work. The crux of such criticism is that self-constitution appears to presuppose an autonomous, self-reflexive subject, which conflicts with his archaeological critique of humanism, and the genealogy of the production of "docile bodies" via disciplinary power relations (see The Order of Things and Discipline and Punish). The concern is not so much with whether there is, or should be, such a thing as the subject. The conflict arises from the view that an externally constituted subject and an autonomous subject with the capacity for critical transformation are incompatible. If the subject is the result of discourse and power relations, then it cannot critically self-transform-dissent and critique are not possible if subjectivity is the product of external structures and systems of control. Yet, I contend that explorations of self-care are an extension of his prior work, and do not contradict earlier arguments on the social and historical constitution of the subject. The subject of self-care remains culturally, socially and historically constituted; however, this does not equate to a passive account of subjectivity that is solely defined by external systems of power and control. The subject remains constituted in the knowledge/power networks, and the conditions for self-understanding remain historically tied to social and discursive practices. However, these conditions do not eliminate the subject's capacity for criticism, self-reflection and resistance (Oksala, 2005, pp. 4-70).

It is true that in numerous contexts Foucault describes subjectivity as the product of processes of systemisation, categorisation and disciplinary power relations. However, the recognition of these systems of control is intended to be liberating rather than confining. In an interview Foucault acknowledges that his work on structures of domination is frequently interpreted as oppressive with no real opportunity for resistance:

\footnotetext{
${ }^{3}$ While investigating the ways in which individuals' see themselves as subjects of sexuality Foucault becomes aware that sexuality is not a singular form of experience and wants to understand how the experience of sexuality, which is accessible to different fields of knowledge and linked to an apparently uniform system of rules and constraints, is constituted. In The Use of Pleasure and The Care of the Self, Foucault uses sexuality and the desiring subject as examples of self-constitution, and explores ways the desiring subject is organised throughout antiquity. Although almost the same prohibitive codes exist in fourth century B.C. Athens as do at the beginning of the Roman empire, Foucault shows that the way these prohibitions integrate with the subject of sexuality are completely different. This is not to suggest that pre-Christian sexuality is less restrictive than postChristian accounts. Later themes of Christian austerity are clearly present in Pagan ethics, but the relationship between these themes and the desiring subject is different. A crucial distinction is the Greeks' privileging of techniques of the self over actual rules for sexual conduct.
} 
"I think that in the public's eye I am the one who has said that knowledge has become indistinguishable from power, that it was only a thin mask thrown over structures of domination and that the latter were always oppression and inclosure, etc. On the first point I will respond with a burst of laughter. If I had said that, or wanted to say, that knowledge was power I would have said it, and having said it, I would no longer have anything to say, since in identifying them I would have had no reason to try and show their different relationships. I directed my attention specifically to see how certain forms of power which were of the same type could give place to forms of knowledge extremely different in their object and structure" (Foucault, 1989b, p. 304).

In revealing external modes of objectification, even before his "ethical turn", Foucault reveals that systems are not innate, timeless and unchanging, but rather something to be questioned and transformed. As he says in the same interview, "[t]he work of the intellectual is not to mould the political will of others, it is ...to re-examine evidence and assumptions, to shake up habitual ways of working and thinking". Instead of "moulding" the will of others Foucault participates in "the formation of a political will" by analysing and re-valuating rules and institutions (Foucault, 1989b, pp. 305-306). Similarly, in pointing out that subjectivity is not innate and unchanging, he is not denying the existence of the subject altogether or reducing it to a passive construction governed solely by external forces. By showing the subject is constructed by external forces, Foucault opens new lines of critique about the meaning of subjectivity — but these lines of critique do not preclude freedom and autonomy.

Foucault's work on knowledge, power and ethics aims to affect the understanding of social reality rather than denying the existence of the subject altogether (Patton, 1998, p. 65). Even in his account of docile bodies, often mistakenly taken to mean that personal agency and selfconstitution are always nothing but illusions, Foucault alludes to possibilities for transformation. ${ }^{4}$ In revealing external contingencies he undermines the "timeless authority" of universal truths, and opens a space for critique, transformation and resistance (McWhorter, 1999). It is possible to draw on fragments from past works on his discussions on the "death of man", or the formation of docile bodies, or interpret them in isolation, and argue that Foucault presents conflicting accounts of subjectivity (Said, 1996; Fraser, 1989; Hacking, 1986; Dews, 1989; Habermas, 1996). However, Foucault's arguments on systems of knowledge, power, and self-constitution are all different ways of approaching the same problem: to critically assess the meaning of governing systems of truth and offer possibilities for change.

Freedom, for Foucault, lies in the attempt to identify alternative discourses to those that constitute subjectivity, and to shape life in the continual response to forms of government and self-government. It is the basis for challenging effects of power and domination and, although there is no end, freedom is most certainly a revolt within practices. As he says:

"Nothing is more inconsistent than a political regime that is indifferent to truth; but nothing is more dangerous than a political system that claims to prescribe the truth. The function of "free speech" doesn't have to take legal form, just as it would be in vain to believe that it resides by right in spontaneous exchanges of communication. The task of speaking the truth is an infinite

\footnotetext{
${ }^{4}$ Being conditioned by knowledge/power networks does not limit the subject to passive classification and manipulation; there is always capacity for movement and change. Paul Patton, positioning himself against critics such as Jürgen Habermas, Ian Hacking and Nancy Fraser, calls this subject the "human material". Jürgen Habermas, Ian Hacking and Nancy Fraser argue respectively that there is no conception of the properly human subject only an "arbitrary partisanship that cannot account for its normative foundations", and that "he has given no surrogate for whatever it is that springs eternal in the human breast", and because of a lack of normative criteria for judgement there is no way of distinguishing between power that does and does not involve domination (Habermas, 1987, p. 276; Hacking, 1986, p. 40; Hoy, 1996, Walzer, 1996, Dreyfus \& Rabinow, 1996, Habermas, 1996; Fraser, 1989, pp. 32-33).
} 
labor: to respect it in its complexity is an obligation that no power can afford to short-change, unless it would impose the silence of slavery" (Foucault, 1989b, p. 308).

Foucault's freedom, including free speech, simultaneously affects and is affected by varying power relations. Freedom is not a transcendent idea but something that is historically changeable, and exists in relation to forms of knowledge and power. Freedom as personal agency manifests in a lack of complicity rather than as essential autonomy. It is the concrete capacity to say 'No!' (O'Leary, 2002, p. 159).

\section{The influence of Pierre Hadot's philosophy as a way of life}

Foucault is critical of the tendency to reduce all social and political problems according to predetermined ends and verifiable procedures. For Foucault, philosophical activity is a condition of possibility for the articulation of the question of the self. For him, every judgment or evaluation is a particular historical event, which leads to the possible reimaginings of current configurations. Transformative possibilities open up in the recognition of the historicity of the question itself. Foucault believes that criticism should be conducted as a historical investigation into "a way of thinking and feeling; a way, too, of acting and behaving" (Foucault, 1997, p. 309). It is what Foucault claims the Greeks called ethos and it is what he terms a care of the self (Foucault, 1988; 1989a). Self-care is not an abstract conception, or a guide for action, but rather it is what he refers to as a critical attitude.

Distinguishing between morality and ethics, Foucault posits that morality is a set of culturally imposed norms enforced onto individuals, whereas ethics concerns questions about how to act, and does not necessarily rely on universal principles. In short, ethics is an active experience and practice, and morality a system of rules. Foucault argues that the moralisation of individuals has expanded to the moralisation of the masses; yet to overcome such a morality does not necessarily result in eliminating ethical questioning all together. In discussing the care of the self, Foucault describes two main types of moral systems: the first is externally enforced, asserts authority, and emphasises moral codes that reference appropriate behaviour according to a law or a set of laws. Foucault provides the Abrahamic religions as examples of the first type of moral system. The second type of moral system focuses on selfrelational ethical practices, where basic rules and codes for behaviour are secondary to the attention on the formation of self within interconnected relationships through techniques and exercises. In this system authority is self-referential and takes a therapeutic or philosophical form. Despite separating ethics and morality, Foucault acknowledges the two are not mutually exclusive. Nevertheless, the contrast is instructive in that it highlights a different approach to understanding the ethical subject (Foucault, 1992, pp. 27-29; Rabinow, 2000, pp. xxvi-xxvii).

Foucault sees in the alignment of the ethical and political subject a possibility for change. In his conception of the care of the self ethics and politics are intertwined-presenting a dynamic, critical relationship as a way to think differently about ethical and political engagement. By changing one's comportment in the world in relation to the self and others, Foucault wants to change the nature of ethical and political thought. As such, he explores ethics as a form of moral subjectivation and as a form of self-constitution, and offers different possibilities for regarding not only the history of sexuality, but also the ethical —and by extension political—subject (Davidson, 2005; Foucault, 1992, pp. 29-30; Rabinow, 2000, p. xxvii). Rejecting a relationship to ethics that is grounded in the established morality of the eternal values of Good and Evil, right and wrong, Foucault becomes attracted to ancient relations of the self that combine regulation and structure with openness and changeability.

In particular, Foucault is interested in Pierre Hadot's interpretation of ancient texts, and the emphasis on the importance of what he terms spiritual exercise. Hadot begins from the premise that it is important to situate ancient thinkers in the "living praxis from which they emanated", rather than assuming they are attempting to construct systems in the same way as 
modern philosophers (Hadot, 1993, p. 8). According to Hadot, a fundamental aspect of this lived praxis is the oral dimension of ancient philosophy, from which the written philosophical works of antiquity are never entirely free. This lived discourse is intended to produce a particular psychic effect in the reader or listener, and not simply to pass on information. As such, dialogical learning equates to being able to philosophise. Hadot posits that a Socratic dialogue is actually a spiritual exercise that calls on a person to pay attention to and care for themselves. Self-knowledge is only possible through a relationship with the self and constitutes the basis of all spiritual exercises. According to Hadot, such spiritual exercises are central to understanding ancient philosophers' writings and their philosophical discourse. Theory is not posited as an end in itself, but is always in the service of ascetic practice. As such, the significance and aim of ancient philosophical discourse is conditioned by the attempt to transform individuals' lives by providing a philosophical art of living.

Foucault uses this idea, of philosophy as an art of living, as the basis for his account of techniques aimed to develop a personal relationship to ethics that is not reliant on universal principles. Although there are guiding principles concerning techniques of the self, for the most part the rules and principles of these techniques, and the form that is given, is personally invented. Unlike the ancient models of self-care that Hadot presents, Foucault does not offer specific practices or guidelines. Foucault's practices of self-care are unspecified, and revolve around notions of personal responsibility, accountability, and a consistency between the truths a person holds publicly and privately, as well with words and deeds. As he says, "the care of the self can be centred entirely on oneself, what one does, on the place one occupies among others" (Foucault, 2000b, p. 295).

Yet, the reduction of practices of the self to ethical exercises alone in The Use of Pleasure and The Care of the Self troubles Hadot. For him, ancient exercises need to be understood in relation to three major areas of philosophy: dialectic (or logic), physics and ethics (Hadot, 1993, pp. 18-29). According to Hadot, in Foucault's reduction of the art of living to ethics alone it is impossible to properly understand the spiritual exercises of antiquity. It is true that ancient ethics puts the rules of life into practice by setting out the principles, distinctions and definitions of virtues and vices as well as a lived ethics, but logic and physics also share these dual elements of theory and practice. For instance, logic concerns propositions, syllogisms, various ways of refuting sophism, and exercises to learn to apply abstract rules, but there is also a lived logic that consists of not consenting to falsities. Again, physics comprises both the theoretical and the lived experience; the latter involving a cosmic consciousness that brings pleasure to the soul. Hadot believes that, in reducing the care of the self to personal ethics, Foucault's account of ascetic practices becomes too narrow. No room remains for a broader consciousness, through which the philosopher can view their relationship to the world. Hadot contends that, by not allowing the self to become aware of its belonging to a whole, Foucault is unable to see the full scope of ancient spiritual exercises where physics, logic and ethics all play an equal part in self-transformation. Hadot writes: "It is quite true that... the ancients did speak of an "art of living". It seems to me, however, that the description M. Foucault gives of what I had termed "spiritual exercises," and which he prefers to call "techniques of the self," is precisely focused far too much on the "self," or at least on a specific conception of self... In fact, the goal of [ancient] exercises is to go beyond the self, and think and act in unison with universal reason" (Hadot, 1995, p. 207).

Hadot is correct in pointing out Foucault's omission of logic and physics from his account of the care of the self. Yet, it seems unlikely that having read Hadot, along with his own meticulous research of ancient texts, Foucault would be completely ignorant of the role of physics and logic in ancient thought and practices of the self. Perhaps logic and physics are not an issue for him because he has already covered what he might see as the equivalent of these two dimensions in earlier work on knowledge and power. Furthermore, Foucault's 
project on self-constitution is not a revival of self-care presented in antiquity but an exploration of practices that might offer new possibilities for current amalgamations of the subject of ethics. A comment Paul Veyne makes, in relation to an unrelated conversation on Foucault's ideas of self-care, demonstrates that Foucault is aware of the idea of a lived physics and logic, but does not consider it to be all that important for his particular project. Following an exchange with Foucault, Veyne says, “[o]ne day when I asked Foucault: "The care of the self, that is very nice, but what do you do with logic, what do you do with physics?', he responded: 'Oh, these are enormous excrescences!', (Veyne, 1991 cited in Davidson, 1995, p. 25; Oksala, 2005, pp. 166-168). Additionally, as Foucault says in "The Return of Morality":

"...I believe that this "fishing around" that one undertakes with the Greeks it is absolutely necessary not to fix the limits nor establish in advance a sort of program that would permit one to say: this part of the Greeks I accept, that other part I reject. The whole Greek experience can be taken up again in nearly the same way by taking into account each time the differences in context and by indicating the part of this experience that one can perhaps save and the part that one can on the contrary abandon" (Foucault, 1989c, p. 325).

Hadot is perhaps correct in his assertion that, to grasp the centrality of ancient spiritual exercises, it is important to include all three areas of philosophical practice. Yet, as is the case with all of Foucault's explorations, he never wants only to understand a way of thinking in the past and reapply it to modern problems. He wants to see how ideas change over time in order to rethink or problematise current issues. Just as modern music takes sounds from the past to create something different yet related, Foucault takes past ideas and ways of thinking and applies them to the present. His interest is in not in learning to play a particular composition note for note, but to look for various ways of approaching the song using current methods, drawing out the similarities and differences, and in the process perhaps revealing something new. ${ }^{5}$ Each era offers different perspectives, worldviews, problematics and concerns that have the potential to reframe current issues, perhaps in such a way as to transform them altogether. Unwilling to accept the current arrangement of dominant systems, Foucault searches for alternative forms of resistance to highlight alternate conceptions of the self and world and to put into question current modes of subjectivation. As he says in one of his later interviews, "The search for styles of existence as different as possible from each other appears to me to be one of the points around which contemporary research could be initiated in particular groups in the past. The search for a form of morality that would be acceptable to everyone -in the sense that everyone would have to submit to it- strikes me as catastrophic" (Foucault, 1989c, p. 330).

Foucault contends that techniques of the self, understood as shaping the continual work of self-critique, analysis and transformation, offer an alternate approach to modern moral systems. Arguing that external moral codes have lost authoritative control with the decline of modern religions Foucault suggests, legislative dictates govern much of what is deemed socially acceptable. However, legal intervention into moral and personal affairs is not necessarily a suitable approach to governing personal behaviour. Inspired by Hadot's philosophy as a way of life, Foucault's "aesthetics of existence" is an approach to ethics (and politics) that is not intrinsically grounded in prescriptive codes based on religious or legislative structures. ${ }^{6}$ Foucault reconceptualises an ethical subject that critically evaluates

\footnotetext{
${ }^{5}$ In any case, despite my claim that Foucault is not interested in all aspects of ancient practices of the self, Hadot is correct when he says: "[ $\mathrm{t}]$ hese differences [in their interpretation of the care of the self] could have provided the substance for a dialogue between us, which, unfortunately, was interrupted all too soon by Foucault's premature death" (Hadot, 1995, p. 206).

${ }^{6}$ Laws against sexual misbehaviour were limited and not severe.
} 
personal behaviour, actions and judgments independent of externally constituted criteria, which ideally could lead to a different form of political thinking. In an interview, when asked about the connection between the care of the self and politics, Foucault responds by saying:

"I admit that I have not got very far in this direction, and I would much like to come back to more contemporary questions to try to see what can be made of all this [whether the care of the self can be located at the heart of a new form of political thought] in the context of the current political problematic. But I have the impression that in the political thought of the nineteenth century - and perhaps one should go back even farther, to Rousseau and Hobbes - the political subject was conceived of essentially as a subject of law, whether natural or positive. On the other hand, it seems to me that contemporary political thought allows very little room for the question of the ethical subject" (Foucault, 2000b, p. 294).

\section{Aesthetics of existence - a never-ending practice}

In contrast with a view that casts subjectivity as unchanging and fundamental, the formation of Foucault's particular kind of subject - a process he refers to as subjectivation - is the result of a complex set of forces acting and reacting upon one another. Modes of subjection are inescapable because, at any given time, there is always a set of historically contingent characteristics and capacities defining how a self-subject is understood, and how she understands herself. Modes of subjection are whatever is internalised and comes to inform the constitution of the ethical subject; this could be holy writ, reason, or political conviction to name a few. Foucault identifies three key factors that constitute the ethical subject ${ }^{7}$ : ethical substance, modes of subjection (internal and external forces of knowledge and power) and ascesis (technique). The particularities of these modes of subjectivity govern a person's thinking and actions, and range from such things as forms of sexual identity to how people are brought to embrace the ideals of a socio-cultural milieu. ${ }^{8}$ Yet, recognising such modes as contingent, albeit necessary, allows for a critical engagement with subjectivity that opens a possibility for transformation. ${ }^{9}$ Foucault's care of the self is one such attempt to reconfigure current arrangements concerning the subject and its relationship to ethics.

Crucial to Foucault's process is the recognition that the self-subject is not given and does not have ontological precedence, and that subjectivity is transformable. This notion of the self-subject as a form to be worked upon and transformed brings me to Foucault account of ascesis or technique. The fundamental point of ascetic practices is that they establish a transformative relation to the self. As such, constant work is necessary to question, shape and transform the self-subject. Examples of asceticism can be moderating acts, self-deciphering, or analysing desires. It can also involve the breaking down of commonly held truths and ideas regarding the world and self. However, unlike the ancient Greek practices that Hadot presents, where there are publicly acknowledged established practices, Foucault advocates developing

\footnotetext{
${ }^{7}$ Ian Hacking includes a fourth element, a teleology - the kind of being to which we aspire when we act ethically (Hacking, 1986).

${ }^{8}$ For example, identifying, and being identified, as homosexual includes a multiplicity of practices that define this "subjectivity", and are simultaneously imposed internally by oneself and externally by the time, place, society, culture, sub-culture and so forth. In an interview with a French gay magazine, Foucault suggests that homosexual subcultures offer the possibility for new forms of subjectivity. Foucault says in an interview, “...[it's] possible that gay culture will be not only a choice of homosexuals for homosexuals - it would create relations that are, at certain points, transferable to heterosexuals" (Foucault, 2000b, p. 160).

${ }^{9}$ Foucault rejects the standard Cartesian model of subjectivity that has come to be the overriding model of subjectivity in modernity. Yet, despite his opposition to such modern configurations, Foucault rejects the possibility of discarding subjectivity - understood as a set of contingent correlates-altogether. Foucault does not deny the subject exists, but he does not see it as a "sovereign, founding subject", or a "universal form of subject that is found everywhere". Modes of subjection that define forms of subjectivity are inescapable, but this is not the same as saying the subject is passively defined. As such, his depiction of a thoroughly constituted subject does not preclude the possibility for self-constituted agency.
} 
techniques that are broad in scope and that differ between people. The key element is that such techniques contribute to an ethics of self-transformation, and are not just learned practices that are repeated unthinkingly. Foucault's self-care is continual, critical, selftransformation that can manifest in practices as varied as sadomasochism ${ }^{10}$ and genealogical critique.

Yet, sadomasochism and genealogy are not in themselves key features of Foucault's conception of ethics as self-care. Not every person interested in sadomasochism is caring for the self, and nor is every person caring for the self engaging in sadomasochism - and the same goes for any other practice. The question that ultimately interests Foucault is - how is it possible, outside of dominant institutional frameworks, to build new forms of affective relationships? The essential feature is an attitude towards the self that embraces the contingency and necessity of subjectivity, and regards the subject as a malleable form. There is a necessary connection between ethics and an attitude towards existence that involves both a critical attitude to the world, and a compulsion to face the task of self-creation that reimagines and transforms modes of behaviour and ways of thinking (Foucault, 1997, pp. 317-320). Truth, subject, and ethics are all viewed as processes aimed to destabilise ossified structures and prevent the imposition of others. Just as with his notion of truth, the ethical subject for Foucault is a process that embraces contingency, and aims at transformation through a number of different paths. Transformation is not an end in itself.

The relationship between ethics and aesthetics manifests through technical and ascetic practices, whereby ethical practice is principally a matter of self-critique and development, and not located in a universal form of the subject. Self-care is the awareness that truth emerges through practice and is not a static essence or pre-given nature (Foucault discusses this in "The Ethics of the Concern for the Self" among other texts). Through processes of reasoned self-critique acted out in physical and mental practices, commonly held ideas, rules and codes are put into question - and affirmed as necessary, transformed, or discarded altogether. A critical attitude between the self and externally posited truths is a foundation for ethical and political engagement, because these truths guide decisions, and extend beyond the self to affect individual judgments of events and actions. It is this idea of truth through practice, rather than as a pre-given foundation, that Foucault sees as offering a possibility for a different account of ethical and political agency.

An aesthetics of existence relates to a development of the ethical subject that is not a matter of learning, internalising, and formalising a set of externally imposed norms that are equally applicable to all (Foucault, 1992, pp. 251-253). To be just and good is tied with enhancing a relationship with the self where people freely work out, invent and select the important principles to guide their life and actions. ${ }^{11}$ In caring for the self, a person embraces the never-ending labour necessary in the art of living, so as to understand the relationship between truth and the self. By confronting one's life to look at what has been, and will be done, practices of self-care enable an understanding of personal ethical existence that is necessary to learning what it means to be just and virtuous. The art of living is a never-ending process with no definite starting-point or ultimate end. ${ }^{12}$ Yet this type of self-care is, for Foucault, central in understanding what it means to live and act ethically because, even if the answers given are not timeless and unchanging, only by thinking about what it means to act

\footnotetext{
${ }^{10}$ Foucault is interested in the various practices in the gay scene, such as Sado-Masochism and how these contributed to a different view of the gay self-subject.

${ }^{11}$ Foucault elaborates this point in what he describes as the "three great arts of conduct" that are developed in ancient Greek thought: dietetics, economics, and erotics. These techniques do not posit universally applicable principles, but comprise exercises that a person chooses to incorporate into life. The various techniques, methods and exercises aid the development of the art of self-conduct and of the ethical subject (Foucault, 1992, p. 251).

${ }^{12}$ As discussed, for the Greeks the care of the self does have an end, in that it is a necessary condition for political life and the governance over others. For the ancient Romans, care of the self is an end in itself.
} 
justly can a person become more just; only by contemplating virtue is it possible to become virtuous.

Foucault's self-analysis, or aesthetics of existence, is an active process and involves continual adjustment in light of the changing circumstances that affect personal comportment within, and towards, the world. It should not be interpreted to imply the existence of a hidden unconscious, or subconscious truth, to be discovered deep within the subject. There is no "hidden truth" or unified "I". The relationship between truth and the self consists in the interplay between structures of knowledge, and active self-constitution within a particular historical context. Access to the truths inherent in a person's life and world is achieved through active processes of self-analysis, rather than the adherence to static rules. Focusing on the relationship between codes of conduct and the self, it is up to each person to come to terms with what a just life entails; an activity that consists of far more than following a system of rules. A fundamental aspect of this questioning is that it implies a view that ethical practice concerns the form of a person's life, rather than achievement of some ultimate purity or unity, the definition of which is always historically contingent. It is in this connection between ethics and aesthetics that Foucault offers a reconceptualization of the ethical subject. It is also this connection between ethics and aesthetics that has exposed Foucault to numerous attacks, suggesting the care of the self is a form of self-obsession. Yet, I argue, such attacks on Foucault's practices of the self are based on a misunderstanding of what is meant when Foucault talks about the "form" of a person's life.

\section{Is self-care selfishness?}

In several interviews during the early 1980s Foucault laments the fact that art has become something related only to objects; he corrects this restricted view of art by claiming that people need to live life as if it were a work of art: "What strikes me is the fact that, in our society, art has become something that is related only to objects and not individuals or to life. That art is something which is specialized or done by experts who are artists. But couldn't everyone's life become a work of art? Why should the lamp or the house be an art object but not our life" (Foucault, 2000a, pp. 260-261). ${ }^{13}$

Foucault contends that in modernity moral principles have become disconnected from the practice of self-care. This idea of the bios as a material for art is something that fascinates Foucault. When speaking about his later work on ethics and the care of the self, Foucault regularly returns to this process of living self-creation, where life is continually shaped and moulded. Yet what does living like a work of art mean, precisely? Surely, Foucault is not simply suggesting that in the absence of universals we concentrate on giving our lives the most beautiful form possible? After all, if this is his proposal, standard problems emerge in relation to the definition of such a beautiful artwork, as well as in relation to the capability of passing judgment over this beauty.

To hold to a division between art, ethics, and knowledge is common in modernity, with Kant being one of the first to enunciate that beauty exists independently of science or ethics. Consequently, the idea of an ethics as an aesthetic process of living self-creation has met with much hostility. In fact, as some of the criticisms mentioned in the introduction demonstrate, to advocate for a care of the self has been regarded by some as synonymous with selfabsorption, and opposed to morality as commonly conceived. However, I contend, Foucault's care of the self does not mean selfishness and to equate it with a notion of concern only for oneself is mistaken. The care of the self is always regarded in relation to others. The self in this model does not exist in isolation, and nor does it disregard the wellbeing of others. On the

\footnotetext{
${ }^{13}$ As I will argue later in this section Foucault's sloppiness in distinguishing between art as travail (process/style) rather than oeuvre (product/object) opens him up to some superficially valid, but generally unwarranted criticism.
} 
contrary, the care of the self always presupposes a concern for the development of others and to view self-care as an escape from rules of ethical conduct, in favour of personal needs, beauty and desires is a fundamental misunderstanding. A misunderstanding that results from unanalysed exclusion of practices aimed at developing a relationship between self and truth through self-analysis and critique.

The fear underlying this line of attack is that without recourse to a prevailing moral structure, such as Aristotelian virtue or Kantian duty, the idea of the self as artwork easily transforms into a politics that treats the masses as raw material to be moulded for diabolical ends; Nazism and Fascism are the readily employed examples to support this case. The primary concern of this critique is that the beautiful illusion of aesthetic expression takes priority over principles of political right. Richard Wolin, among others, sees Foucault's emphasis on aesthetics as a kind of immorality that points towards a "politics of nihilistic catastrophe" (Wolin, 1986, p. 85). ${ }^{14}$ His primary fear is that approaching life as aesthetic expression could have catastrophic implications because of the abandonment of any grounds for what is right, with the possible outcome of an amoral free-for-all.

I contend that this line of criticism is more a reflection of the critic's assumptions about the nature of morality than a direct engagement with Foucault's work on practices of the self. I am not by any means suggesting Foucault's ideas are without problems but, as I will show, many of the attacks on this front arise from a need to defend a particular moral system rather than from a genuine debate with Foucault's ideas. Andrew Thacker, for example, demonstrates this view when he argues that Foucault confuses the ancient Greek and Kantian sense of aesthetics. He argues that the two approaches are incongruous because the ancient Greek form of aesthetics relates to perception-for example to be seen to be living a good life - and is interconnected with social and ethical practices. The Kantian understanding of aesthetics, however, relates to matters of taste, characterised by disinterested delight, where aesthetics serves no ends other than its own. The possibility of some "semantic slipperiness" is initially an interesting observation until it becomes evident that Foucault's "confusion" emanates from Thacker's refusal (or inability) to let go of his Kantian understanding of aesthetics. His Kantianism guides his subsequent attack of Foucault's aesthetics of existence-when quoting Foucault's use of aesthetics, Thacker remarks that Foucault's use is "clearly not recognisably Kantian" because the autonomy of the aesthetic is negated and subjective aspects rather than universal codes inform the ethics (Thacker, 1993, p. 14).

Thacker's argument, along with others like Wolin and Peter Dews, rests on the premise that aesthetics and ethics are incompatible and any attempt to combine the two is dangerous. Dews argues that it would be anachronistic to fuse Kantian and ancient Greek aesthetics. The key point in this line of criticism is the necessity to keep the ethical and aesthetic realms separate, because modern day conceptions of aesthetics do not contain ethical or social practices (Dews, 1989, p. 37; Thacker, 1993, p. 14). For example, Thacker claims that today it is impossible to capture the ancient concept of aesthetics because art objects contain no intrinsic ethical meaning. For Wolin, an aesthetics of existence may lead to good relations between interlocutors through discussions of what actions are considered beautiful, stylish and good, but its application to spheres other than artistic practice could result in praising actions that are manipulative and predatory (Wolin, 1986, pp. 79, 84). Terry Eagleton expands on this concern, suggesting that without moral codes it is impossible to approve or disapprove of an action that is aesthetically appealing. He puts the problem this way: "what would a stylish rape look like?" He argues that the best to hope for is an aesthetics of existence based on autonomy and not ethics (Eagleton, 1991, p. 394). Without principled guidelines there is no way to determine between what is and is not an ethical act. The problem with an aesthetics

\footnotetext{
${ }^{14}$ Timothy O’Leary presents a counter argument to Wolin’s views (O'Leary, 1996).
} 
of existence, as it is understood within all three of these critiques, is that it cannot provide a necessary framework by which to condemn certain acts as wrong. ${ }^{15}$

This raises the broader issue, mentioned earlier, concerning not only morality and ethics but the significance of any criteria, internal to an aesthetic practice, by which to judge something as significant. Foucault turns to ancient ideas of the self to demonstrate the limits of, and find alternatives to, standard approaches to universally applicable moral systems. As I mentioned earlier, Foucault's self-care is not amoral or context free. Practices of self-care always exist in relation to universal ideas such as justice or virtue, but these ideas are not in themselves beyond critique. Furthermore, a personal relationship to truth, as this relates to the understanding of universal principles, does not exist independently of the world and others. Such truths guide and facilitate a person's actions and judgments. However, these "truths", which serve as an ethical orientation, are not timeless and beyond question. The care of the self is a practice that continually assesses, reaffirms and discards the foundations that provide meaning and guidance, and although these "personal truths" appeal to universal ideals, they are not universally applicable to all at all times and, as such, no action can be said to be inherently bad or good, and no idea of virtuous acts is beyond critique.

Thacker, Wolin and others set up their attacks by locking Foucault's work into a space he is trying to disrupt. Each assumes their ethical framework as beyond critique, and regards any attempt to question this premise as a dangerous deviation. Thacker, Wolin, Dews and Eagleton do not entertain the possibility of developing a different kind of ethical attitude. Instead, each attacks Foucault's aesthetics of existence, made manifest through practices of self-care, as simply a concern with beauty and style, regardless of the nature of the actions (as in Eagleton's appeal to the "Foucauldian possibility" of a "beautiful rape"). Interestingly however, in Thacker's critique, despite his principled rejection of self-care he demonstrates a momentary awareness of Foucault's project. After "demonstrating" the disastrous consequences of Foucault's aesthetics of existence, based on modern conceptions of aesthetics, Thacker states that the best Foucault can hope for by looking back to the ancient Greeks is a reminder that our present configuration of ideas is not set in stone and is capable of rearrangement. Yet just as quickly as he suggests present configurations of thought may not be timeless, Thacker casts this "absurd" notion aside. The result is that Thacker engages with the idea of aesthetics from one perspective and does not entertain the possibility that perhaps his own "configuration of these various realms is not set in stone" (Thacker, 1993, p. $15)$.

By ignoring Foucault's actual account of the care of the self, critics of his aesthetics of the self appeal exclusively to an understanding of aesthetics that is separate from any ethical structure. This restricted view of aesthetics allows them to equate the care of the self with selfishness, and conclude that the striving for beauty, at best, is ethically blind and, at worst, leads to horrendous actions. At no time do any of these criticisms engage with the conception of self-care and aesthetics that Foucault presents. This critique of Foucault's self-care rests on a fundamental failure to understand the challenge of living a life of continual, critical selfcreation that Foucault puts forward as an alternative to morally prescriptive systems. Rather than explore the possibilities of different ethical systems, Thacker and the others set up attacks to allow them to reaffirm the superiority and necessity of a universal ethics.

To explain the criticism Foucault faces from thinkers like Dews, Thacker, Wolin and Eagleton, Arnold Davidson points out that in most Anglo-American moral philosophy, developing a relationship with the self is not considered ethically relevant (Davidson, 1996, pp. 231-232). When such relations do appear, they generally concern the question of personal

\footnotetext{
${ }^{15}$ Taylor, Walzer, Fraser and perhaps the best known critic, Habermas, present the dangers of Foucault's lack of normative guidelines. Habermas and Foucault were set to have a debate on this very topic but unfortunately due to Foucault's untimely death this never took place (Taylor, 1996; Walzer, 1996; Fraser, 1989; Habermas, 1987).
} 
duties, usually presented as a list of prohibitions. Additionally, discussions of such duties are always limited, and considered of less importance than the duties towards others, since the latter are seen to be more complex and numerous. Davidson cites Alan Donagan as an example of this approach. Davidson claims that, after proposing a fairly traditional list of prohibitions against self-mutilation, suicide and diminishing health, Donagan attempts to determine how demanding these duties are and when exceptions are permitted. Yet, despite presenting a work that primarily concerns a discussion about self-directed duties, Donagan nonetheless opens with the claim, "[a]s we shall see, the relations which human beings can have to one another are more complex than those they can have to themselves" (Donagan, 1977, p. 76).

Such standard approaches to moral philosophy, which predominantly concern ethical codes and ignore the role of self-relation in ethical judgment, is evident in the above critiques of Foucault's idea of an aesthetics of existence. For critics from the Anglo-American tradition, bound by its appropriation of Kantian moral philosophy, the only relevance a relationship to the self can hold is in the desire to make the moral code complete, and in the wish to know what specific personal duties (if any) a person has. Yet from Foucault's perspective, there is little difference between these Kantian heirs and Schopenhauer's claim that there are indeed no such duties at all, because both ethical approaches ignore the multifaceted and complex relationship to the self. As Davidson concludes:

"Even if our duties to others are more complex than our duties to ourselves, our relations to ourselves have all the complexity one could ever hope for, or fear. By showing how to embed our relations to ourselves in a grid of ethical intelligibility, Foucault has helped to articulate the kind of complexity these relations actually embody. Unless moral philosophers supplement their discussions of moral codes with ethics a la Foucault, we will have no excuse against the charge that our treatises suffer from an unnecessary but debilitating poverty" (Davidson, 1996, pp. 231-232).

Foucault reveals the complex nature of ethics by suggesting that perhaps the application of moral codes is not necessarily the same as acting ethically, and nor should ethics be reduced to the adherence to universal moral codes. As Davidson's argues, the "grid of ethical intelligibility" encompasses a diverse range of relations that are not so readily reduced to a duty toward others.

In defending Foucault against criticisms such as those put forward by Wolin, I point out that Foucault's idea of "art" must not be approached as if it were a finished product (as in a "beautiful rape"), but as an ongoing process. The art of life is not the completion of a final object, but the process of artistic creation. Timothy O'Leary makes a similar point when he suggests that although Foucault uses the conventional French expression oeuvre d'art, his "work of art" would be better understood as travail (process) rather than oeuvre (product) (O'Leary, 2002, p. 127).

\section{Art as process}

In discussions on an aesthetics of existence, Foucault's use of "art" exists in the space between ancient notions of technique and modern ideas of art as beautiful objects. As Paul Veyne points out, in ancient Greece an artist is firstly an artisan and an artwork a work (Veyne, 1986, pp. 993-994). This notion of aesthetics is fundamentally different to Wolin's and Thacker's idea of aesthetic production because art-work here is taken as a verb and not a noun. In light of the distinction between art as process and art as object, perhaps Thacker's comment concerning Foucault's semantic slipperiness is valid. However, the "slipperiness" is not dues to Foucault's confusing the ancient Greek and Kantian sense of aesthetics, as 
Thacker suggests, but rather in Foucault's shift between art as process and art as product, between art as technique and art as beauty.

Foucault's aesthetics of existence cannot be reduced to a mere concern with style, at the exclusion of the practice and work of living that is fundamental to his account of care. O'Leary's distinction between process and product is helpful in this regard because it more accurately reflects the concerns Foucault presents in his lectures on The Hermeneutics of the Subject. In these lectures Foucault provides varying accounts of care as an end in itself, and his repeated emphasis on self-care echoes Nietzsche's call for "long practice and daily work" (Foucault, 2000a, p. 351). In using the term "aesthetics", Foucault simultaneously references both technique, as in physical and mental practices, and beauty, such as an "aesthetically pleasing piece of art"; and it is precisely Foucault's failure to adequately highlight his movement between process and product, technique and beauty that leaves his account vulnerable to attack from critics such as Wolin (Foucault, 2000a, p. 348). Such critics focus on Foucault's aesthetics of existence in terms of the beauty of the finished product, and omit the continual process of work and development inherent in his account of self-care. However, fears such as Eagleton's concerning a "beautiful rape" are only possible if one refuses to acknowledge that the care of the self does not have the creation of a "beautiful" product as its end.

The idea of life as constant work forms the basis of Foucault's ethical subject. It is the form life takes, rather than the creation of a self-object that gives it meaning, and it is in this meaning that the ethical subject is constituted. In contrast to modern moral precepts, self-care does not posit a set of fixed rules that ought to hold equally to all people and situations. The care of the self is a process of self-analysis and development rather than an adherence to a strict set of universals, through which personal belief systems and the truths that provide meaning to the world are confronted. Foucault believes there are no fixed customs and norms that can universally dictate appropriate modes of behaviour, and neither is there a transcendental self to discover. To rephrase my earlier point, the care of the self evaluates the consistency between those truths regarded as necessary, and a person's actions in the world.

In light of the distinction between art as process-technique and product-beauty, I suggest Foucault's joining of ethical and aesthetic practices is the result of the technical, ascetic mode of these practices. His call to live life like a work of art refers to life lived as a constant process rather than the achievement of a final form of beauty, purity or unity. The practice of life as a work of art, and the constitution of the ethical subject, is not just about living as an artistic practice. Life as art refers to the constant process of critique and creation necessary for understanding the truths a person esteems above all else, and the manifestation of these truths not just in words said to others, but through lived practice and action.

\section{Conclusion - the political and ethical implications of self-care}

The task Foucault sets, in articulating an ethical practice based in freedom, is to bring out ascetic practices from the realm of art, and place them into politics and society more broadly. He makes self-care central to the expansion of resistance, with ethics serving as the mediator between the subject, knowledge and power. Through a critical attitude towards the present via an individual ethics, based on a specific notion of freedom, Foucault questions the limits imposed upon us and experiments with ways to reconfigure such limits. Simply, the care of the self is the acknowledgement that a person exists in a world that cannot be transcended, whilst simultaneously remaining an active part in it. At its core is a concern with developing a personal relationship to truth and manifesting that truth in words and deeds, whilst continuing to question those truths made manifest. Taking the Nietzschean line that all truths are interpretations, the care of the self does not discover an ultimate hidden truth deep within the soul-it is never-ending exercise, work and vigilance. 
Self-care involves creating different modes of existence by identifying historically contingent aspects where there is more freedom than first appears. Practices of the self are not merely individual, and nor are they entirely communal, but always relational and interconnecting. Furthermore, because freedom is a field of possibility instead of a fixed state, the work never ceases. The task of giving form to a person's life, and their engagement with others, is a project without completion; the ethical concern for the self is an infinite labour. In O'Leary's words, "[i]f the aim of critical philosophy is to help us untie the knots of our identity, then the aim of ethics is to work out ways of retying them in new and less constraining ways" (O'Leary, 2002, p. 170). It is about preparing to be a subject of action within the world, rather than being removed from it. Situated within the world, the care of the self is about the constitution of a person as a self-constituted subject of action.

Self-care as an aesthetics of existence concerns analysing, unravelling and re-constituting inherited forms of individual and collective life that have become intolerable. The aim of the care of the self is not to give life the most beautiful, stylish form nor is it a self-satisfied contemplation or introspection, a pining for the fulfilment of some authentic self. As he says, "[n]ot only do I not identify this ancient culture of the self with what you might call the California cult of the self, I think they are diametrically opposed" (Foucault, 2000a, p. 271). The care of the self is not a narcissistic, self-obsessed quest for a lost inner truth; it is a lived ethics based on immanence, vigilance and distance - with immanence understood as the sense in which care of the self includes placing an order on life that is not underpinned by transcendent values or external conditions. It is a state of constant attentiveness to what is determined and determinate, both from within and without.

The subject continually questions, discards and re-creates, as need be, the organising systems and truths inherent in a particular world-view through the critical task of ongoing critique manifest in practices of self-care. This awareness of the contingency of systems of knowledge and power is essential for the development of an independent ethico-political attitude. The critical task for Foucault is to question and challenge oppressive systems of power and control. The ability to refuse, to judge particulars, to identify forms of domination, all contribute to the opening-up of the space of freedom. Freedom is the capacity to refuse to participate and say "No! I cannot", and to sound a warning through actions and deeds. Freedom is the capacity to identify personal and cultural contingencies, to discard that deemed unnecessary, and retain that which is not. In Foucault's care, ethics and politics cannot be separated, because both are constitutive features necessary for informed civic activity.

In the end, most simply, an aesthetics of existence is an attitude towards the self, life and the world. The cultivation of techniques can assist in the task of transformation, and create spaces for political resistance and change, self-care is a never-ending, critical approach to externally and internally imposed truths. The care of the self serves as a form of critique and resistance where it is both a way of living and acting in the world, and a critical response to a particular time and place. With the care of the self Foucault introduces a relationship to ethics that does not necessarily rely on universal principles and is not grounded in pre-determined codes of conduct. His approach to ethics concerns the act of creation rather than the finished product. It demands continual exercise and work, and through this a relationship to the self is established. This exercise and critique entails ongoing vigilance - in not only questioning the world and events, but also personal truths and points of view. The care of the self is a regulative principle of activity, and of relationships with the world and others. It is an attitude towards existence that affects self-understanding, life and action, and becomes the constitutive principle of political and civic activity, because of the connection between practices of the self and self-transformation in the face of fixed modes of subjectivity. Although Foucault never systematically lays out his understanding of the link between 
philosophy as a way of life and politics, it is, without a doubt, a connection he regards as important. Foucault's later works develop an account of self-constitution centred on the critique and analysis of self, world and others. Most simply, Foucault presents an idea of personal existence as a willingness and openness to put even the most sacred ideas to the test, and this offers possibilities for transformation, political resistance and change.

\section{References}

DAVIDSON, A. I. (1995): Introduction: Pierre Hadot and the Spiritual Phenomenon of Ancient Philosophy. In A. I. Davidson (ed.): Philosophy as a Way of Life. Oxford: Blackwell, pp. $1-45$.

DAVIDSON, A. I. (1996): Archaeology, Genealogy, Ethics. In: D. C.Hoy (ed.): Foucault: A Critical Reader. Oxford : Blackwell, pp. 220-233.

DAVIDSON, A. I. (2005): Introduction. In: A. I. Davidson (ed.): Michel Foucault. The Hermeneutics of the Subject. Lectures at the College de France 1981-1982. New York: Palgrave MacMillan, pp. xix-xxx.

DEWS, P. (1989): The Return of the Subject in late Foucault. In: Radical Philosophy, 51(Spring), pp. 37-41.

DONAGAN, A. (1977): The theory of morality. Chicago: The University Press of Chicago.

DREYFUS, H. L. \& RABINOW, P. (1996): What is Maturity? Habermas and Foucault on 'What is Enlightenment?'. In: D. C. Hoy (ed.): Foucault. A Critical Reader. Oxford: Blackwell, pp. 109-122.

EAGLETON, T. (1991): Ideology of the Aesthetic. Oxford: Blackwell.

FOUCAULT, M. (1988): Technologies of the Self. In: L. H. Martin, H. Gutman, \& P. H. Hutton (eds.): Technologies of the Self. A seminar with Michel Foucault. Amherst: University of Massachusetts Press, pp. 16-49.

FOUCAULT, M. (1989a): The Aesthetics of Existence. In: S. Lotringer (ed.): Foucault Live. New York: Semiotext(e), pp. 309-316.

FOUCAULT, M. (1989b): The Concern for Truth. In: S. Lotringer (ed.): Foucault Live. New York: Semoitext(e), pp. 293-308.

FOUCAULT, M. (1989c): The Return of Morality. In: S. Lotringer (ed.): Foucault Live. New York: Semiotext(e), pp. 317-332.

FOUCAULT, M. (1990): The Care of the Self. The History of Sexuality: 3. London: Penguin Books.

FOUCAULT, M. (1992): The Use of Pleasure. The History of Sexuality: 2. London: Penguine Books.

FOUCAULT, M. (1994): The Order of Things. An Archaeology of the Human Sciences. New York: Vintage Books.

FOUCAULT, M. (1997): What is Enlightenment. In: P. Rabinow (ed.): Ethics. Essential Works of Michel Foucault 1954-1984. Volume 1. London \& New York: Penguine, pp. 303320.

FOUCAULT, M. (2000a): On the Genealogy of Ethics: An Overview of Work in Progress. In: P. Rabinow (ed.): Ethics. Essential Works of Foucault 1954-1884. London: Penguin Books, pp. 253-280.

FOUCAULT, M. (2000b): The Ethics of the Concern for the Self as a Practice of Freedom. In: P. Rabinow (ed.): Ethics. The Essential Works of Foucault 1954-1984. volume 1. London: Penguin Books, pp. 281-302.

FOUCAULT, M. (2000c): The Social Triumph of the Sexual Will. In: P. Rabinow (ed.): Ethics: Essential Works of Foucault 1954-1984. London: Penguin, pp. 157-163.

FRASER, N. (1989): Unruly Practices: Power, Discourse and Gender in Contemporary Social Theory. Cambridge: Polity Press. 
HABERMAS, J. (1987): The Philosophical Discourse of Modernity. Cambridge: Polity. HABERMAS, J. (1996): Taking Aim at the Heart of the Present. In: D. C. Hoy (ed.): Foucault. A Critical Reader. Oxford: Blackwell, pp. 103-108.

HACKING, I. (1986): Self-Improvement. In: D. C. Hoy (ed.): Foucault. A Critical Reader. Oxford: Blackwell, pp. 235-240.

HACKING, I. (1986): The Archeology of Foucault. In: D. C. Hoy (ed.): Foucault: A Critical Reader. Oxford: Blackwell, pp. 27-40.

HADOT, P. (1993): La philosophie antique: une éthique ou une pratique ? In: P. Demont (ed.): Problèmes de la Morale Antique. Amiens: Faculté des Lettres, pp. 7-37.

HADOT, P. (1995): Reflections on the Idea of the "Cultivation of the Self". In: P. Hadot \& A. I. Davidson (eds.): Philosophy as a way of Life. Oxford: Blackwell, pp. 206-213.

HADOT, P. (1997): Forms of Life and Forms of Discourse in Ancient Philosophy. In: A. I. Davidson (ed.): Foucault and His Interlocutors. Chicago \& London: The University Press of Chicago, pp. 203-224.

HADOT, P. (2002): Exercises Spirituels et Philosopie Antique (2nd ed.). Paris: Gallimard.

HOY, D. C. (1996): Power, Repression, Progress: Foucault, Lukes, and the Frankfurt School. In: D. C. Hoy (ed.): Foucault. A Critical Reader. Oxford: Blackwell Publishers, pp. 123-148.

MCWHORTER, L. (1999): Bodies and Pleasures. Foucault and the Politics of Sexual Normalization. Bloomington: Indianna University Press.

OKSALA, J. (2005): Foucault on Freedom (1st ed.). Cambridge \& New York: Cambridge University Press.

O'LEARY, T. (1996): Foucault, Politics and the Autonomy of the the Aesthetic. In: The International Journal of Philosophical Studies, 4(2), pp. 273-291.

O'LEARY, T. (2002): Foucault and the Art of Ethics. New York \& London: Continuum.

PATTON, P. (1998): Foucault's Subject of Power. In: J. Moss (ed.): The Later Foucault. London: Sage, pp. 64-77.

RABINOW, P. (2000): Introduction. In: P. Rabinow (ed.): Ethics. Essential Works of Foucault 1954-1984. volume 1. London: Penguin Books, pp. xi-xlii.

RABINOW, P. (2009): Foucault's Untimely Struggle: Towards a Form of Spirituality. In: Theory, Culture, Society, 26(6), pp. 25-43.

SAID, E. W. (1996): Foucault and the Imagination of Power. In: D. C. Hoy (ed.): Foucault. A Critical Reader. Oxford: Blackwell, pp. 149-156.

TAYLOR, C. (1996): Foucault on Freedom and Truth. In: D. C. Hoy (ed.): Foucault. A Critical Reader. Oxford: Blackwell, pp. 69-102.

THACKER, A. (1993): Foucault's Aesthetics of Existence. In: Radical Philosophy, 63(Spring), pp. 13-21.

VEYNE, P. (1986): Le dernier Foucault et sa morale. In: Critique, 471(2), pp. 933-941.

VEYNE, P. (1991): Le renouveau de l'histoire ancienne prépare-t-il un nouveau siecle des Lumieres? In: R. Pol-Droit (ed.): Les Grecs, les Romains et Nous. L'Antiquite est-elle Modern?. Paris: Le Monde, pp. 57-68.

WALZER, M. (1996): The Politics of Michel Foucault. In: D. C. Hoy (ed.): Foucault. A Critical Reader. Oxford: Blackwell, pp. 51-68.

WOLIN, R. (1986): Foucault's Aesthetic Decisionism. In: Telos, 67(spring), pp. 71-86. 